\title{
An Analysis of the Attitudes of the Teacher Candidates towards the Game of Chess
}

\author{
Reşat Sadik*, Nurgül Tezcan Kardaş \\ Sport Sciences Faculty of Sports Administration, Düzce University, Turkey
}

Copyright $\bigcirc 2018$ by authors, all rights reserved. Authors agree that this article remains permanently open access under the terms of the Creative Commons Attribution License 4.0 International License

\begin{abstract}
Purpose of this study is to analyze the attitudes of the teacher candidates studying at universities towards the game of chess and determine to what extent these attitudes are affected by some variables. In this study, survey model was used. As data collection tool, "Attitude Scale for the Game of Chess" was used, developed by Sadık et al., having factor loads ranging from .76 to .94 , being one-dimensional, consisting of 16 items, with total explained variance of $86 \%$, and with Cronbach's Alpha reliability co-efficient of .98 . The study group consisted of 451 teacher candidates studying at the university. Research data was analyzed by using IBM SPSS 22.0 program. In analyzing the data, t-test and one way analysis of variance (ANOVA) were used for frequency independent samples. As a result of the analysis, it was found that the attitudes towards chess did not differ according to gender variable, whereas they showed significant differences according to class and department variables. Findings were discussed in the context of literature, and various suggestions were made about the field of chess education.
\end{abstract}

Keywords Chess, Attitude, Teacher, Teacher Candidate, Teachership

\section{Introduction}

Chess is a game played between two players, and it requires many skills. It is played on a chessboard with two different colors and $(8 \times 8)=64$ squares. Each player has an army of chess pieces in his command. One of the players commands white pieces, while the other commands the black ones [1]. Today, there are many different opinions and explanations about chess. Chess is a game that most serious people have devoted their lives to, and there are huge volumes published on chess [2]. World Chess Federation (FIDE - Federation Internationale Des Echecs) defines chess as "a game played between two opponents who move their pieces alternately on a square board called a 'chessboard'.
The objective of each player is to place the opponent's king 'under attack' in such a way that the opponent has no legal move. The player who achieves this goal is said to have 'checkmated' the opponent's king and to have won the game. The opponent whose king has been checkmated has lost the game. If the position is such that neither player can possibly checkmate, the game is drawn" [3]. For [4], "chess is a game of intelligence. It is brain gymnastics incarnate. It can be played between two individuals, as well as between many people simultaneously, even by a single person by himself, or against a computer [4]. When the common notions about chess are considered, it is seen that [2] characterizes chess as a game to which important people have devoted their lives, and about which many studies have been carried out. Reti sees chess as an art and science, which is new and ever developing [2]. There are numerous scientific studies arguing that the game of chess impacts the cognitive and affective development of individuals. Chess is seen not only as a sport, but also as a means to contribute to the education of the students. For, as a game of strategy, chess has multi-faceted academic effects such as analytical thinking, problem solving, and applying mathematical concepts [5]. Research on chess found that children who had chess education in early childhood were more successful in mathematics and various cognitive skills than those who did not have chess education [6]. It was concluded that the students who could play chess had better problem solving skills than those who could not [7]. Another study established that, as the level of knowledge concerning chess increases in middle school students, they display a more positive attitude towards problem solving [8]. Considered as a projection and a simulation of life, chess is commonly agreed to have positive and permanent effects of children's education. It can be said that chess helps bring up individuals with high concentration and attention. For, the situations that arise in a game of chess require extensive analysis. The most appropriate move emerges after the static and dynamic analyses of various situational elements [9]. Chess is a tactile, activity-oriented game that promotes critical thinking and lends itself to self-directed learning [10]. Chess is a game 
based on pieces having quantitative and geometrical features. Playing chess depends on a child's ability to calculate, in accordance with the rules, the value of pieces and the number of moves required to reach the target. Chess exercises can be used for teaching the general strategies necessary for solving mathematical problems [11]. It is undoubtedly of utmost importance that a game so effective in imparting the mentioned positive characteristics to individuals is taught and liked by the students. This can certainly be achieved in a more qualified way by means of educational institutions. Accordingly, teachers have the most important role to play in this mission. Teachers have always held a critical position in transferring a society's cultural values, knowledge, and skills to the younger generations [12]. Teachership is rapidly gaining importance, and the classical methods and techniques of teaching are being replaced by teachers, who provide their students with critical perspectives, guide them by following technology and using the newest and most effective teaching materials [13]. According to one of the commonly agreed upon definitions, a teacher is "a person who has been trained and is appointed for guiding and leading the learning processes of children or youth at a public or private educational institution." Engaged in educational production together with students in an educational environment, a teacher is the person with an expertise in her field, who prepares an effective learning environment, guides the students and their parents [14].

Teaching requires expertise. Therefore, it is of utmost importance that the teacher candidates should be trained as well-educated and qualified teachers. Teacher candidates should also have those "qualifications that a teacher must possess." These qualifications are divided into two as professional and personal qualifications. Professional qualifications of a teacher consist of general knowledge, knowledge of the field, knowledge and skills about teaching, whereas the personal qualifications contain the individual's proclivity to the profession of teaching, and the traits of being a role-model that teachership requires [15].

This study aims at establishing the viewpoints of teacher candidates concerning chess, which can be utilized as an effective means in introducing many positive qualities to the students. Analysis of the said perspectives as attitudes is pertinent to the purpose of this study. Attitude is a mental, emotional, and behavioral reaction disposition towards any object, social topic, or event and is organized by the individual based upon his experience, motivation, and knowledge [16]. Attitude is an inclination attributed to an individual and regularly shaping her opinions, feelings, and behaviors towards a psychological object [17]. Simply put, an attitude calls a person to accept or not accept, approve or disapprove, say yes or no to a situation. In other words, an attitude has a characteristic of steering a person to action [18]. Therefore, "attitudes" are forms of feeling, thinking, and behavior of individuals towards other individuals, situations, and objects. As a result of the attitudes they form, they lead individuals to behave in certain ways. Attitudes cannot be observed; but by assessing the behaviors of individuals, one can understand what their attitudes are and what qualities they have [19]. In this study, it is aimed to investigate the attitudes of the teacher candidates, who are not yet teachers but studying at universities, towards the game of chess, especially in the context of their respective fields of teaching.

\section{Materials and Methods}

This section presents information on the research model, study group, data collection tools, data collection and analysis.

\subsection{Research Model}

Carried out in order to determine whether the attitudes of teacher candidates towards chess vary in accordance with some variables, this study used survey model within the context of descriptive method. A descriptive research is the primary and fundamental research activity, and it has a great significance in acquiring and advancing knowledge. Most of the problems of education are of descriptive nature [20]. Survey models are research approaches that aim at describing a past or present situation as it was or as it is [21]. Such studies mostly seek answer to the questions concerning the current condition of the said case or problem, and where we stand in relation to it [22]. For [23], such studies aim at describing the demographic features of the group researched, their attitudes towards and opinions of the situation or the fact in question.

\subsection{Study Group}

Study group consists of students from the department of teaching at Düzce University, during the academic year 2017-2018. The students participating in the study were chosen by the method of random sampling. Distribution of the students in terms of departments, class standing, and gender is given in Table 1 .

As it is seen in Table 1, out of 451 participants in total, 197 $(43.7 \%)$ are male, and $254(56.3 \%)$ are female. When the school departments of the participants are examined: 108 (23,9 \%) are from the Department of Physical Education and Sports; 71 (15,7\%) are from Classroom Teaching; 54 (12,0\%) are from Turkish Language Education; $43(9,5 \%)$ are from English Language Education; 55 (12,2\%) are from Science Education; 53 (11.8\%) are from Pre-school Education; and $67(14.9 \%)$ are from the Department of Psychological Counseling and Guidance. As for their years; 98 (21.7\%) are freshman; 176(25.1\%) are sophomore; 75 (15.0\%) are junior; and 102 are $(24.0 \%)$ senior. To the question whether they know how to play chess, 331 teacher candidates $(73.4 \%)$ answered positively, whereas $120(26.6 \%)$ responded negatively. 
Table 1. Distribution of the Demographic Features of the Participants

\begin{tabular}{cccc}
\hline & VARIABLES & $\mathrm{N}$ & $\%$ \\
\hline \multirow{3}{*}{ Gender } & Male & 197 & 43,7 \\
& Female & 254 & 56,3 \\
& Total & 451 & 100 \\
& Physical Education and Sports & 108 & 23,9 \\
& Turkish Language Education & 54 & 12,0 \\
Department & English Language Education & 43 & 9,5 \\
& Science Education & 55 & 12,2 \\
& Classroom Teaching & 71 & 15,7 \\
& Pre-school Education & 53 & 11,8 \\
& Psychological Counseling and Guidance & 67 & 14,9 \\
Class Standing & Total & 451 & 100 \\
\hline \multirow{2}{*}{ Do you know how to play } & $1^{\text {st }}$ year & 98 & 21,7 \\
chess? & $2^{\text {nd }}$ year & 176 & 39,0 \\
$3^{\text {rd }}$ year & 75 & 16,6 \\
$4^{\text {th }}$ year & 102 & 22,6 \\
& Total & 451 & 100 \\
\hline
\end{tabular}

\subsection{Data Collection Tool and Data Collection}

In order to determine the attitudes of the teacher candidates towards chess, "Personal Information Form, prepared by the researcher, and "Attitude Scale Towards the game of Chess", a Lickert-type scale of 5 points, the validity and reliability of which was tested by [24], were used.

The categories of this scale used for determining the attitudes of teacher candidates consisted of "totally disagree", "disagree", "undecided", "agree", "totally agree." Comprised of 26 positive and 22 negative items during the stage of improving, the scale later became a scale of 16 positive items as a result of the analyses. In the overall scale, Content Validity Index (CVI) was found to be .95 . If CVI is greater than .80 , then this is sufficient in terms of content validity. Low CVI items, on the other hand, are eliminated [25]. To improve the scale, 15 people in total took part in with their expertise, including people from the fields of assessment and evaluation, program development, Turkish language, and chess trainers of $2^{\text {nd }}$ level and senior chess trainers. The highest score that can be obtained from the scale is 80 , and the lowest is 16 . KMO value of the scale was found to be 0.94 , and Barlett test was 10400,885 and $p<0,01$, whereas the explained variance was found as,

86.153. Factor load values vary between .76 and .94 . For [23], it is a good yardstick that factor load values are 0.45 or greater. Cronbach Alpha Value of the one-dimensional "Chess Game Attitude Scale" was found to be .97, and as a result of the test-retest method, a high correlation was found between the two measurements taken at two different times. Data was collected by visiting the participants at their classrooms, and on a voluntary basis after the necessary explanations were made.

\subsection{Data Analysis}

In line with the purpose of the study, statistical analyses of the data concerning the information, the answers to which was sought, were done by means of SPSS 22.0 (Statistical Packet for Social Sciences) packaged software. From the descriptive statistical methods, (f) frequency, (\%) percentage, and $(\bar{x})$ arithmetic mean were analyzed; and since the date shown normal distribution, from the parametric tests, t-test and AVOVA were used for determining the differences between independent variables. In multiple comparisons, "Scheffe Test" from Post Hoc Tests was used in order to establish the direction of the difference.

\section{Results}

This section presents statistics and the values given, in proportion to various variables, to the points of the teacher candidates they scored from the data collection tool.

The general average of attitudes of the teacher candidates, studying at the departments of teaching, towards the attitude scale on game of chess is found as follows:

Table 2. Attitude Scale General Statistics

\begin{tabular}{cccccc}
\hline & N & Minimum & Maximum & Average & sd \\
\hline General & 451 & 1.00 & 4,94 & 2,5155 &, 79568 \\
Average & 451 & & & & \\
\hline
\end{tabular}

In Table 2, the average of the 451 participants is $\bar{x}$ $=2.5155$, and its standard deviation is .79568

The test results of the teacher candidates, studying at the departments of teaching, towards the attitude scale on game of chess are found, with respect to gender, as follows: 
Table 3. Game of Chess Attitude Scale, Gender Variable, $\mathrm{T}$ Test Results

\begin{tabular}{cccccc}
\hline & $\mathrm{sex}$ & $\mathrm{n}$ & $\overline{\mathrm{x}}$ & $\mathrm{sd}$ & $\mathrm{p}$ \\
\hline $\begin{array}{c}\text { Attitude } \\
\text { towards chess }\end{array}$ & Male & 197 & 2,57 &, 83 & \\
& Female & 254 & 2,47 &, 76 &, 168
\end{tabular}

As it can be seen in Table 3, attitude scores of the teacher candidates in terms of gender variable are $\bar{x}=2,57 \pm .83$ in average for the males $(n=197)$, and $\bar{x}=2,47 \pm .76$ for the females $(n=254)$, whereas p value is .168 .

The test results of the teacher candidates, studying at the departments of teaching, towards the attitude scale on game of chess are found, with respect to whether they can play chess or not, as follows:

Tablo 4. Game of Chess Attitude Scale, $T$ Test Results with respect to variable of whether they can play chess or not

\begin{tabular}{cccccc}
\hline \multirow{2}{*}{$\begin{array}{c}\text { Attitude } \\
\text { towards } \\
\text { chess }\end{array}$} & $\begin{array}{c}\text { Do you know } \\
\text { how to play } \\
\text { chess? }\end{array}$ & $\mathrm{N}$ & $\overline{\mathrm{x}}$ & $\mathrm{sd}$ & $\mathrm{p}$ \\
\cline { 2 - 6 } & Yes & 331 & 2,36 &, 75 & \\
& No & 120 & 2,93 &, 75 &, $000^{*}$ \\
\hline
\end{tabular}

$\mathrm{p}<0.05^{*}$

When Table 4 is examined, it is seen that the teacher candidates who responded negatively to the question whether they could play chess $(n=120)$ scored an average of $\bar{x}=2.93 \pm .752$, whereas those who responded positively $(n=331)$ scored an average of $\bar{x}=2.36 \pm .756$, while the $p$ value is .000 .

The test results of the teacher candidates, studying at the departments of teaching, towards the attitude scale on game of chess are found, with respect to their departments, as follows:

Table 5. Game of Chess Attitude Scale, T Test Results with respect to variable of whether they can play chess or not

\begin{tabular}{|c|c|c|c|c|c|c|c|}
\hline \multirow{12}{*}{$\begin{array}{c}\text { Attitude } \\
\text { towards } \\
\text { chess }\end{array}$} & Department & $\mathrm{n}$ & $\overline{\mathrm{x}}$ & $\mathrm{Sd}$ & Df & $\mathrm{F}$ & $\mathrm{p}$ \\
\hline & $\begin{array}{c}\text { Physical } \\
\text { Education } \\
\text { and Sports }\end{array}$ & 108 & 2,63 & ,78 & 6 & 7,488 & $.000^{*}$ \\
\hline & Turkish & & & & & & \\
\hline & Language & 54 & 2,90 & 1,05 & & & \\
\hline & Education & & & & & & \\
\hline & English & & & & & & \\
\hline & Language & 43 & 2,47 &, 35 & & & \\
\hline & Education & & & & & & \\
\hline & $\begin{array}{c}\text { Science } \\
\text { Education }\end{array}$ & 55 & 2,27 &, 59 & & & \\
\hline & $\begin{array}{l}\text { Classroom } \\
\text { Teaching }\end{array}$ & 71 & 2,27 & 62 & & & \\
\hline & $\begin{array}{l}\text { Pre-school } \\
\text { Education }\end{array}$ & 53 & 2,18 &, 81 & & & \\
\hline & $\begin{array}{c}\text { Psychological } \\
\text { Counseling } \\
\text { and Guidance }\end{array}$ & 67 & 2,74 &, 84 & & & \\
\hline
\end{tabular}

When the Table 5 is examined, the following averages found according to the departments of the participants, and the $\mathrm{P}$ values was found .000: the average of the students of Physical Education and Sports $(n=108)$ was $\bar{x}=2,63 \pm .78$; the average of the students of Turkish Language Education $(n=54)$ was $\bar{x}=2,90 \pm 1.05$; the average of the students of English Language Education $(n=43)$ was $\bar{x}=2,47 \pm .35$; the average of the students of Science Education $(n=55)$ was $\bar{x}=2,27 \pm .59$; the average of the students of Classroom Teaching $(n=71)$ was $\bar{x}=2,27 \pm .62$; the average of the students of Pre-school Education $(n=53)$ was $\bar{x}=2,18 \pm .81$; and the average of the students of Psychological Counseling and Guidance $(n=67)$ was $\bar{x}=2,74 \pm .84$.

The test results of the teacher candidates, studying at the departments of teaching, towards the attitude scale on game of chess are found, with respect to their class standings, as follows:

Tablo 6. Game of Chess Attitude Scale, "One Way Anova" Results with respect to variable of the participants' class standings

\begin{tabular}{cccccccc}
\hline & $\begin{array}{c}\text { Class } \\
\text { Standing }\end{array}$ & $\mathrm{n}$ & $\overline{\mathrm{x}}$ & $\mathrm{sd}$ & $\mathrm{df}$ & $\mathrm{F}$ & $\mathrm{p}$ \\
\cline { 2 - 7 } Attitude & $1^{\text {st }}$ year & 98 & 2,40 &, 66 & 3 & 4,577 & $.004^{*}$ \\
Towards & $2^{\text {nd }}$ year & 176 & 2,62 &, 86 & & & \\
Chess & $3^{\text {rd }}$ year & 75 & 2,65 &, 70 & & & \\
& $4^{\text {th }}$ year & 102 & 2,32 &, 81 & & & \\
\hline
\end{tabular}

$\mathrm{p}<0.05^{*}$

As it can be seen from the Table 6 , the average of the $1^{\text {st }}$ year students $(n=98)$ was found $\bar{x}=2,40 \pm .66$; the average of the $2^{\text {nd }}$ year students $(n=176)$ was found $\bar{x}=2,62 \pm .86$; the average of the $3^{\text {rd }}$ year students $(n=75)$ was found $\overline{\mathrm{x}}=2,65 \pm .70$; and the average of the $4^{\text {th }}$ year students ( $n=102$ ) was found $\bar{x}=2,32 \pm .81$, while $P$ value was found to be .004 .

\section{Discussion and Conclusion}

In this section, findings obtained by means of statistical analyses concerning the teacher candidates' attitudes towards chess are evaluated and interpreted.

One of the most important objectives of education is to train qualified individuals, which is closely related to the education of teachers. An important problem that faces us is to train the teacher candidates as well-equipped with the necessary knowledge and skills. One of these skills is the game of chess, about which various studies have been conducted, and which is agreed to be an important tool in education. Chess is a game of intelligence. Games of intelligence are another tool that can be used for educational purposes and that has the potential of affecting the thinking skills like problem solving [26] and the general academic achievement of the students [27] learning chess. Classified as Games of Intelligence (logical games-brain teasers-puzzlers) by [28], these games can be exemplified by games such as Tangram, Kendoku, Sudoku, Puzzle, Checkers, Chess, Word Hunt. Analyzing the attitudes towards chess, a game that has an important place 
among the said games of intelligence, this study has reached several findings. When the attitudes of the teacher candidates towards chess are analyzed, it can be said that the general attitude is at the medium level. The study entitled "Opinions of Social Science Teacher Candidates on Games on Intelligence" conducted by means of group interview by [29] found that the teacher candidates generally thought positively about the games of intelligence, which they thought to have the characteristics to enrich and variegate the teaching-learning environment. In the study entitled "Opinions of the Primary School Mathematics Teachers about the Course on Games of Intelligence" conducted by [30], it is stated that the teacher candidates in general expressed their positive opinions and believed that the course of games of intelligence would contribute to mathematics education in general, and to mathematical skills in particular. According to the findings of the study conducted by [8], a high correlation was observed between the levels of chess knowledge of middle school students and their attitude scale scores about solving mathematical problems. Accordingly, it was found that the more knowledgeable were they about chess, the more positive attitudes the students had towards solving mathematical problems. The study by [31], concluded that teaching chess to five and six year old children at pre-school period could contribute to improving children's attention. A study conducted by [32], entitled "Chess Training and Mathematical Problem-solving: the Role of Teaching Heuristics in Transfer of Learning" verified the hypothesis that chess training improved children's mathematical skills and that knowledge of general problem solving methods in chess can be transferred to the field of solving mathematical problems. A study by [33], concluded that chess training given to pre-school children positively affect children's cognitive development and contribute to their social development as well. When it is examined whether the teacher candidates' attitude levels concerning chess vary with respect to their gender, findings show no statistically significant difference. Therefore, it is not possible to say that gender has a significant impact in this regard.

When it is examined whether the teacher candidates' attitude levels vary in terms of their responses to the question "do you know how to play chess?" there was a statistically significant difference. In other words, the attitudes of the participants towards chess varied depending on whether they knew how to play chess or not. Teacher candidates who could play chess scored higher in their attitude levels than those who could not. The study conducted by [34] and entitled "Examination of the Effect of Playing Chess on the Metacognitive Ability and Power of Solving Mathematical Problems of Students from Different Levels of Education" established that the student who played chess displayed higher achievement both in cognitive and mathematical problem solving skills in comparison to the students who did not play chess.
When the attitude scale scores of the teacher candidates were examined, with respect to the variable of department, a statistically significant difference was found, which was in favor of the teacher candidates from the department of Turkish Language Education, whose attitude scale scores concerning chess were found to be higher than the teacher candidates from the departments of "Physical Education and Sports", "Classroom Teaching", "English Language Education", "Science Education", "Pre-school Education", "Psychological Counseling and Guidance."

When the effect of the variable of class standing on attitudes was examined, a statistically significant difference was found in favor of the $3^{\text {rd }}$ year students, who had higher scores in the attitude scale.

In conclusion, it was found that the attitude levels of the teacher candidates were lower than expected, did not vary in terms of gender, and varied according to the department variable in favor of the department of Turkish Language Department, as well as in favor of the $3^{\text {rd }}$ year students in terms of class standing, and in favor of those who can play chess in terms of the variable of whether they could play chess or not. Considering that the study can add a new dimension to the field, it can be suggested that studies with different groups should be made, and the findings thus obtained should be supported with different variables and qualitative data. Indeed, our system of education badly needs educational tools like chess, which are effective in imparting positive qualities to individuals.

\section{Acknowledgements}

The authors thank Emrecan AZILI who participated in this study.

\section{REFERENCES}

[1] Pritchard, D. B., trans. Y1lmaz Kemal PEKER, Beginer Chess, İstanbul: Mediterranean Publishing, 1998.

[2] Reti, R. Masters of Chessboard, Modern Chess Pieces (trans. Ali Karatay). İstanbul: Broy Publishing, 2000.

[3] Federation Internationale Des Echecs - FIDE. Laws of chess. Retrieved from https:/www.fide.com/fide/handbook.html?id=207\&view=a rticle., 2017.

[4] Averbach, E. Chess Endings 2nd Print, Trans: Aydın Umur. İstanbul: Broy Publishing, 2000.

[5] Aydın, M. Examining the impact of chess instruction for the visual impairment on mathematics. Educational research and reviews, 10 (7), 907-911, 2015.

[6] Tekneci, S. S. Analysis of the Effect of Chess Training During Pre-school Period on the Mathematical Skills of the Primary School 1st Grade Students. Master's Thesis, 2009. 
[7] Sadık, R. A Comparison of the 4th and 5th Grade Primary School Students Who Can Play Chess and Those Who Cannot, and Their Respective Success in Four Operations with Natural Numbers and Problem Solving. Abant İzzet Baysal University, Institute of Social Sciences, Master's Thesis, 2006.

[8] Büyükaşık, E. Correlation between the Middle School Students' Attitudes towards Problem Solving and Their Levels of Konowledge of Chess. Mersin University, Institute of Educational Sciences, Unpublished Master's Thesis, 2017.

[9] Suetin, A. Three Steps to Chess Mastery (Trans: Selim Palavan \& Ümit Ünkan). İstanbul: İnkilap Yayınevi, 1994.

[10] Barrett, D. C. \& Fish, W. W. Our move: Using chess to improve math achievement for students who receive special education services. International Journal of Special Education, 26, 181-193, 2011.

[11] Sala, G.,Gorini, A. and Pravettoni, G. Mathematical problem solving abilities and chess: An experimental study on young pupils. Sage journals, July-September, 1-9, 2015.

[12] Hoşgörür, V., Kılıç, Ç. and Dündar, H. 16, 91- 100. Attitudes of Students at Kirıkkale University, Classroom Teacher Program, Towards Teachership, 2002.

[13] Dağ, E. Correlation between the Attitudes of Classroom Teacher Candidates towards the Profession of Teaching and the Factors that Determined their Decision to Choose Teaching (Example of İzmir Province). Ege University. Institute of Social Sciences, Master's Thesis, 2010.

[14] Bek, Y. Social/Professional Roles and Status of Teachers. Master's Term Project, Trakya University, Institute of Social Sciences, 2007.

[15] Çınar, İ. Importance of Primary Education] Journal of Education, 20, 2008.

[16] İnceoğlu, M. Ankara: Elips Book. Attitude, Perception, Communication, 2004.

[17] Kağıtçıbaşı, Ç. İstanbul: Evrim Yayınevi. New Human and Human Beings, 2005.

[18] Akgül, B. M. Evaluation of the Attitudes of Individuals from Different Cultures towards Spare Time Activities. Example of Anakara and London. PhD Dissertation. Gazi University, Insititute of Health Sciences, 2-4,18-20,91-92. 2011.

[19] Kan, A. ve Akbaş, A., Development of Attitude Scale towards High School Students' Chemistry Course. Mersin: Mersin University Journal of Education Faculty, 1 (2), 227-237., 2005.

[20] Balc1, A. Scientific Research Methods in Education, Ankara:
Pagem Publishing, 2001

[21] Karasar, N. Scientific Research Method, (19. Print). Ankara: Nobel Publishing., 2009.

[22] Çepni, S. Introduction to Research and Project Studies, Trabzon: Celepler Publishing. 2007.

[23] Büyüköztürk, Ş. Manual of data analysis for social sciences.Ankara: Pegem Publishing. 2014.

[24] Sadık, R., Özen, A. and Öntürk, Y. Developing an Attitude Scale on Chess 2. International Congress of Graduate Education Congress, (ss 911). 12 - 14 Mayıs 2017.

[25] Davis, L.L. Instrument review: Getting the most from a panel of experts. Applied Nursing Research, 5:194-197, 1992.

[26] Ott, M., \& Pozzi, F. Digital games as creativity enablers for children. Behaviour \& Information Technology, 31(10), 1011-1019, 2012.

[27] Bottino, R. M., Ott, M., \& Tavella, M. Children's performance with digital mind games and evidence for learning behaviour. Information Systems, E-learning, and Knowledge Management Research (pp. 235-243), 2013.

[28] Mitchell, A., \& Savill-Smith, C. The use of computer and video games for learning A review of the literature. London: Learning and Skills Development Agency, 2004.

[29] Ekiçi, M., Öztürk, F. and Adalar, H. Opinions of Social Sciences Teacher Candidates on Games of Intelligence Researcher: Social Science Studies, 5(4), 489-502, 2017.

[30] Ulusoy, A.Ç., Saygı, E. and Umay, A. Opinions of the Primary School Mathematics Teachers on Games of Intelligence, 32(2): 280-294, 2017.

[31] Tatlipınar, S. Effect of Chess Training on the Development of Attention in Pre-school Children. Selçuk University, Institute of Social Sciences, Unpublished Master's Thesis, 2017.

[32] Trinchero, R. and Sala, G. Chess training and mathematical problem-solving: the role of teaching heuristics in transfer of learning. Eurasia Journal of Mathematics, Science \& Technology Education, 12(3), 655-668, 2016.

[33] Akay, K. Examination of the Effect of the Chess Training Given to Pre-school Children on Cognitive and Social Behavior, Necmettin Erbakan University, Institue of Educational Sciences, Unpublished Master's Thesis, 2017.

[34] Kazemi, F. vd. Investigation the impact of chess play on developing meta-cognitive ability and math problem-solving power of students at different levels of education. Procedia - Social and Behavioral Sciences, 32, $372-379,2012$. 